\title{
7 Play in Children with Visual Impairments
}

\subsection{Basic Issues on Play in Children with Visual Impairments}

As mentioned in Chapter 1, "play is a range of voluntary, intrinsically motivated activities normally associated with recreational pleasure and enjoyment” (Garvey, 1990). Play is also the child's main 'job'. It is often associated mainly with its visual aspects-looking at the toys, and thus, playing with them, seeing the play-partners, and initiating a game together, or in other words, engaging in the play activity through establishing a visual control, visual collaboration, and visual participation.

Many researches have been dedicated to play in children with visual impairments; within these studies, comparison are often offered, with respect to play, among the groups of blind, low-vision, and sighted children. Most of them conclude that visually impaired children, in general, experience major challenges and delays in many developmental areas, including play. According to Lowenfeld (1948), for instance, the limits of blind children are situated in the following three main areas:

a. In the control of the environment and the self in relation to it.

b. In the ability to get about.

c. In the range and variety of concepts.

Other researchers (Rowland, 1985) report that the delays and limitations experienced by visually impaired children and adults may include:

a. Sensory delay.

b. Social delay (difficulties in the quality and quantity of social relations).

c. Political delay (limits in the political and social awareness that their condition must be protected with egalitarian rights).

On the other hand, studies revealed that visually impaired children and sighted children have equal levels of development in many other areas, such as:

- Language development (Kirk \& Gallaghar, 1979)

- Cognitive development and the intellectual abilities (Bateman, 1963; Litvak, 1985).

- School achievements (Gomulicki, 1961).

The famous blind Italian educator Augusto Romagnoli indicates that the blind child acquires through play the awareness of self, of the others and of their otherness, experiences solidarity and cooperation. So, play must be pursued as a principle of maximum socialisation (Romagnoli, 1924).

Based on these findings, one may expect that play is also delayed or compromised in blind and low-vision children. Different studies confirm this assumption. For 
instance, a Nordic study about five-year-old children in kindergartens identified four separate behaviour patterns (Sommer, 2003):

a) Social interactive behaviour. The child:

- is able to focus his or her attention on and follow the intentions of other children;

- is able to mark and follow his or her intentions, ideas, and desires - but is also able to adapt them to the interests of other children;

- is able to interpret and size up the intentions and enterprises of other children;

- is able to act in order to facilitate that his or her intentions and enterprises are carried out;

- is often able to leave his or her mark on the mutual interaction in the group in a positive way through his or her intentions, initiatives, and enterprises;

- is characterised as well integrated in the group of children.

b) Self-marking behaviour. The child:

is characterised by a strong motivation for being 'seen and heard';

tries to catch the attention and interest of others to show himself or herself off;

shows individuality and competes noticeably with others to claim the social scene.

c) Adaptation-ready. The child:

- is able to contribute to the execution of activities in the group thanks to his or her great attention to the intentions of others and good social 'ear';

- is seldom a soloist;

- is able to follow others' proposals and agenda-through social acts, not in the form of passive submission;

- only marks his or her intentions weakly and to a modest extent;

- is able to follow an agenda determined by others-but has minimal influence on the group's agendas; he or she seldom opposes other children's agendas;

- often experiences that his or her proposals are ignored by others who are more dominant and better at applying various instruments of power-often he or she experiences talking without anyone paying attention;

- often leaves it up to others, adults, and children, to choose his or her social contacts, others making contact to other children on his or her behalf.

d) Socially isolated behaviour. The child:

- generally has only sporadic interactions with others;

- receives few and weak initiations of contact from other children. As a consequence, the child is often ignored or overlooked by others;

- uses more active strategies to avoid or break a social contact;

- experiences lack of success in making contact with others, and this results in minor attention to the other children's intentions as well as in reduced ability to follow these intentions;

- withdraws from interactions with other children and withdraws to inner fantasy world;

- sometimes may turn into a socially excluded child, if the isolation is severe and consistent. 
Blind children often have difficulty in becoming or showing socially competent in interactions on their own with sighted friends. They may use self-marking behaviour as a necessity in order to be acknowledged-heard and seen-by the others. However, positive self-marking behaviour may often develop into negative behaviour, because self-marking behaviour is only positive if it is adopted with moderation. Blind children's behaviour patterns may have some points of similarity with behaviour patterns that are normally observed in adaptation-ready and socially isolated children (Ingsholt, 2009). It is important to note that these differences in social skills affect the play behaviour. Many studies have shown that children with visual impairments show a high variability in social competence skills, a compromised social interaction and show that this limits the play behaviour: in kindergarten they are less enterprising, while only seldom they look for interactions with peers and propose games and activities (Celeste, 2006; Parsons, 1986; Skellenger et al., 1997; Zanandrea, 1998).

In addition, Schneekloth (1989) discovered that blind children spent playing alone $56 \%$ of their play time, while low-vision children spent only $33 \%$ of this time alone, compared to $14 \%$ in children without any visual impairment. The same author also found out that sighted children spent most of their play time interacting with their peers, while visually impaired spent $1 / 3$ of their play time in interactions with adults.

A comprehensive study of Fraiberg (1977) compared visually impaired and sighted children in their play activities. She discovered that blind students had significant delays in many play areas-for example, they did not perform imitative play before 30-36 month. An earlier research of Fraiberg and Adelson (1973) suggested that even the concept of self in blind and low-vision children was delayed because of their poor and rare engagement in symbolic, pretend, and fantasy plays. According to the authors this is due to the fact that sighted children started to imitate the household life by taking care of a doll, for instance, at the age of 24 months, while blind children did not demonstrate this type of play before the age of 36-42 months.

Later, a similar study was carried by Troster and Brambring (1994). The authors concluded that sighted children engaged in more complex levels of play at an earlier age than the blind children did; the blind children interacted less frequently with their peers than the sighted children did; furthermore, the blind children preferred tactile-auditory games and toys and rarely engaged in symbolic games.

Similarly, other studies (Parsons, 1986; Lewis et al., 2000; Tioli, 2006) confirm a substantial difference in the playing capabilities of blind children, indicating that the blind child has a delay in the onset of mental image that later gives rise to the emergence of symbolic play. The blind child remains engaged for long in play activities that include: exploration of own body, and undifferentiated manipulation of an object, in a nonfunctional modality, without specific purposes. These are, therefore, activities of repetitive and stereotyped solitary play. Not only the symbolic 
play appears much later than in sighted children, that is in a span of time between the second year of life and the end of preschool age, but also the constructive play-where child learns to place objects in relation to each other (for example, to build a tower with toy blocks or doing a puzzle)-is compromised due to manual and bimanual coordination difficulties, less coordination and orientation abilities.

In 1995, the Bielefeld longitudinal study on early intervention and family counselling for blind infants and preschoolers (Brambring et al., 1995) assessed all areas of development, comparing the blind and sighted children's performances. In 2005, Brambring presented some results of the longitudinal studies held in the University of Bielefeld, which included the findings on 107 skills analysed in a comparative way between blind and sighted children, divided into four areas.

- Manual and daily living skills

- Gross motor skills

- Social interaction

- Language

Table 7.1. shows a few examples, where blind children experience serious delays in different play activities.

Table 7.1. Play delays in blind children (Brambring, 2005)

\begin{tabular}{lll}
\hline Skill & $\begin{array}{l}\text { Sighted children } \\
\text { (age in months) }\end{array}$ & $\begin{array}{l}\text { Blind children } \\
\text { (age in months) }\end{array}$ \\
\hline Building a tower with three toy blocks & 15 & 29 \\
Finding two identical objects in a set of five objects & 26 & 42 \\
Beating a drum rhythmically with two drumsticks & 11 & 37 \\
\hline
\end{tabular}

One very comprehensive literature review on play in visually impaired children was made by Rettig (1994). One of the findings in this research was that vision and communication were both very important, especially in the case of social play with peers, and in this regard, some forms of play may be difficult to perform by blind or low-vision children. Furthermore, Rettig (cit.) adds that visually impaired children have limited play experience in their play, and these are due to delays in different developmental areas. This applies to a great extend to:

1. Practice play

2. Pretend or symbolic play

3. Social play

4. Play with rules

5. Creative play

6. Associative play 
Visually impaired children demonstrate a delay in their symbolic play-at the age of 25,9 months (Rogers \& Puchalski, 1984). Fariberg (1977) even prolonged this delay, stating that blind children do not participate in pretend and imitation play before 30-36 months of age. Fraiberg and Adelson (1973) suggested that the delayed acquisition of the concept of self in visually impaired children is associated with the delay in their symbolic play.

This point of view is confirmed more recently by Brambing (2004) who described the difficulty of the process of separation-individuation not only as a cause of limited self-perception of the child with visual impairment, but also as the cause of his or her late speech development, especially in regard to the late appearance of the first person singular. This last-that is the initial delay in language development-is also explained (Rowland, 1984; Hatwell, 2003) in relation to the lack of the prelinguistic child/mother dialogue through facial expressions and proxemics.

Brambing (2004) also underlined that, when symbolic play appears in the blind child, it is not based on the use of objects, rather on role-play games. This may be due to the fact that for the blind child it is easier to understand and use the process of symbolisation through acknowledging a similarity of reciprocal body movements and exchanges between people than through a similitude of objects. This hypothesis confirms that during the development of these children the emphasis is on the verbal aspects of their life, and also demonstrates that the initial language delay can be perfectly compensated.

On the other hand, some forms of play may not be so difficult for children with visual impairments, and they may feel engaged in them without great effort; as to the possible kinds of play activities, it is the case of, for example: functional play, constructive play play with language fantastic play, storytelling.

\subsection{Strategies for Compensation of the Delays and Difficulties in Play by Children with Visual Impairments}

Rettig and Salm (1992) suggested five strategies for intervention in order to support and to improve the play behaviours of young children with visual impairments:

1. Specific instructions for developing play skills

2. Use of toys

3. Adaptation of the environment

4. Including peers without disabilities

5. The role of adults

The first strategy includes actions as: a) providing the blind babies and infants with as many real objects as possible; b) helping symbolic play; c) avoiding the stereotyped behaviours and mannerisms and so on; d) enhancing sense of self to foster social development (Rettig, 1994); e) encouraging intrinsic motivation, active engagement, flexibility, spontaneity (Recchia, 1997). 
The second strategy includes: a) demonstrating the child on how to use the different toys he or she has at home; b) providing the blind child more tactile and/or musical toys.

The third strategy suggests to help the visually impaired children to orient and move effectively and autonomously in their play environment and to feel comfortable and safe there. Schneekloth (1989) states that play environments that are appropriately designed for children with visual impairments need to be "accessible, safe, exciting and complex" (1989: 201). This strategy also includes to design ordinary learning environments opportunities for play and to adapt learning environments to make them accessible to the impaired child in inclusive contexts (Rogow, 1983; Staccioli, 2010).

The fourth strategy proposed to introduce gradually sighted playing companions to the visually impaired child (at first only one). In addition, Rettig and Salm (1992) suggested to provide some adult supervision when visually impaired and sighted children play together in order to encourage any spontaneous interactions and to avoid any discriminative behaviours. The interaction between the blind child and his or her peers is important not only for access to associative and cooperative play in view of his or her development and pleasure, but mostly to give them the opportunity to fully exercise one of their rights: in fact, participation in recreational, play, leisure, and sport activities, including those in the school system, is precisely cited in the UN Convention on the Rights of Persons with Disabilities (2006, Art. 31), historically most denied in case of sensory disability.

Lastly, the fifth strategy suggests different levels of participation of adults (parents, early carers, and other professionals) in the visually impaired child's play. Rettig (1994) refers a gradual withdrawal of parents and other adults from playing with the children with visual impairments. Tioli (2006) also advances that the role of the adult becomes more and more insignificant during these children's development. On the contrary, the play of these children should be first led by the adult, who should commensurate it to the child's ability but also propose higher level of performance; not too high, however, so that the child does not feel frustrated and the attempt to increase the complexity of play does not fail. Only at that point, when the child has successfully experienced some types of play and feels more confident with this activity, a play free from adult intervention can be proposed.

\subsection{Conclusion}

Many authors underline the significance of play for the overall child development. Experiences from the early periods of child's life, when play is the main activity a child is engaged in, form the basis for subsequent social development in adults (SuttonSmith, 2001; Ingsholt, 2009; Tzvetkova, 1994). Augusto Romagnoli was one the first educators to indicate that the blind child acquires through play the awareness of self, 
of others. and of their otherness, experiences solidarity and cooperation. So, play must be pursued as a principle of maximum socialisation (Romagnoli, 1924).

However, visually impaired children are able to build their play skills similarly to sighted children, with some difficulties or delays. As the Russian educator and psychologist Vygotskij noted: "In the end there is no fundamental difference between the sighted and the blind child [...] and the whole process of development is one and the same for blind and sighted children" (1983:95).

\section{References}

Alliegro, M. (1993). L'educazione motoria dei minorati della vista. Il gioco e lo sport [Motor education of persons with visual impairments. Play and sport]. Roma, I: Armando.

Bateman, B. (1963). Reading and Psycholinguistic Processes of Partially Seeing Children. Arlington, VA: Council for exceptional children.

Brambring, M., Beelmann, A., Buitenhuis, S., Hecker, W. Kurp, C., Licher-Eversmann, G., \& Muellerm A. (1995). Fruefoerderung blinder Kinder. Konzepzion und Peadogogische Psychologie, 37(4), 173-183.

Brambring, M. (2004). Lo sviluppo nei bambini non vedenti. Osservazione e intervento precoce [Visually impaired children's development. Observation and early intervention]. Milano, I: Franco Angeli.

Brambring, M. (2005, August). Assessing Developmental Differences in Blind versus Sighted Children. Keynote speech at the ICEVI European conference, Chemnitz, G. Retrieved from: http://www.icevi-europe.org/chemnitz2005/icevi-chemnitz2005.pdf.

Celeste, M. (2006). Play Behaviours and Social Interactions of a Child Who Is Blind: In Theory and Practice. Journal of Visual Impairment \& Blindness, 100(2), 75-90.

Erwin, E. J. (1993). Social participation of young children with visual impairments in specialized and integrated environments. Journal of Visual Impairment \& Blindness, 8(7), 138-142.

Fraiberg, S. (1977). Insights from the Blind. Comparative Studies of Blind and Sighted Infants. New York, NY: New American Library.

Fraiberg, S., \& Adelson, E. (1973). Self-representation in language and play: Observations of blind children. Psychoanalytic Quarterly, 42, 539-562.

Garvey, C. (1990). Play. Cambridge, MA: Harvard University Press.

Gomulicki, B. R. (1961). The Development of Perception and Learning in Blind Children. Cambridge, UK: Cambridge University: The psychological laboratory (mimeo).

Hayhoe, S. (2014, June). A Grounded Theory Investigation into the Philosophical and Pedagogical Theories of Play by Bind and Visually Impaired Children. Presented at the 6th Biennial Conference of the International Froebel Society "Play, Self-activity, Representation and Development", Canterbury, UK.

Hatwell, Y. (2003). Psychologie cognitive de la cécité précoce [Cognitive psychology of early blindness]. Paris, F: Dunod.

Ingsholt, A. (2009, July). Social Inclusion of 4-6-years-old Blind Children. What Social Competencies Do Blind Children Need? How Can They Best Be Strengthened? Presented at the ICEVI European conference, Dublin, Ireland.

Kirk, S., \& Gallaghar, J. (1979). Educating exceptional Children, Boston, MA: Houghten Mifflin Company.

Lewis, V., \& Collis, G. M. (1997). Blindness and Psychological Development in Young Children. Leicester, UK: British Psychological Society. 
Lewis, V., Norgate, S., Collis, G., \& Reynolds, R. (2000). The consequences of visual impairment for children's symbolic and functional play. British Journal of Developmental Psychology, 18(3), 449-464.

Litvak, A, G. (1985). Тифлопсихология. [Psychology of the Blind]. Moscow, RUS: Education.

Lowenfeld, B. (1948). Effects of Blindness on the Cognitive Functions of Children. In: B. Lowenfeld (Ed), Berthold Lowenfeld on Blindness and Blind People. Selected Papers (pp. 67-78). New York, NY: AFB.

MacCuspie, P. A. (1992). The social acceptance and interaction of visually impaired children in integrated settings. In: S. Z. Sacks, L. S. Kekelis, \& R. J. Gaylord-Ross (Eds.), The Development of Social Skills by Blind and Visually Impaired Students: Exploratory Studies and Strategies (pp. 83-102). New York, NY: American Foundation for the Blind.

Parsons, S. (1986). Function of play in low vision children: I. A review of the research and literature. Journal of Visual Impairment \& Blindness, 80(3), 627-639.

Parsons, S. (1986). Function of play in low vision children: II. Emerging patterns of behavior. Journal of Visual Impairment \& Blindness, 88(6), 777-784.

Recchia, S. L. (1997). Play and Concept Development in Infants and Young Children with Severe Visual Impairments: A Constructivist View. Journal of Visual Impairment \& Blindness, 91(4), 401-416.

Rettig, M. (1994). The play of young children with visual impairments: characteristics and interventions. Journal of Visual Impairment and Blindness, 88(5), 410-420.

Rettig, M., \& Salm, K. (1992, April). The Importance of Play in the Early Childhood Special Education Curriculum. Paper presented at the 70th Annual Conference of the Council for Exceptional Children, Baltimore, Maryland.

Rogers, S. J., \& Puchalski, C. B. (1984). Development of Symbolic Play in Visually Impaired Young Children. Topics in Early Childhood Special Education, 3(4), 57-63.

Rogow, S.M. (1983). Social routines and language play: Developing communication responses in developmentally delayed blind children. Journal of Visual Impairment \& Blindness, 77(1), 1-4.

Romagnoli, A. (1924). Ragazzi ciechi [Blind children]. Bologna, I: Zanichelli.

Rowland, C. (1984). Preverbal communication of blind infants and their mothers. Journal of Visual Impairments and Blindness, 78(7), 297-302.

Rowland, W. P. (1985). Being Blind In The World. Pretoria: South African National Council for the Blind.

Sacks, S. K., Kekelis, L. S., \& Gaylord-Ross, R. J. (1992). The Development of Social Skills by Blind and Visually Impaired Students: Exploratory Studies and Strategies. New York, NY: American Foundation for the Blind.

Sandler, A-M, \& Wills, D.M. (1974). Preliminary notes on play and mastery in the blind child. Journal of Child Psychology, 1(3), 7-19.

Schneekloth, L. H. (1989). Play environments for visually impaired children. Journal of Visual Impairment \& Blindness, 83, 196-201.

Skellenger, A., \& Hill, E. (1994). Effects of a shared teacher-child play intervention on the play skills of three young children who are blind. Journal of Visual Impairment \& Blindness, 88, 433-445.

Skellenger, A. C., Rosenblum, L. P., \& Jager, B. K. (1997). Behaviors of Preschoolers with Visual Impairments in Indoor Play Settings. Journal of Visual Impairment \& Blindness, 91(6), 519-530.

Sommer, D. (2003). Barndomspsykologiske facetter. Århus, DK: Systime A/S.

Staccioli, G. (2010). Includere nel gioco. In: S. Besio (Ed.), Gioco e giocattoli per il bambino con disabilità motoria [Play and toys for the child with motor impairment] (pp. 73-81). Milano, I: Unicopli.

Sutton-Smith, B. (2001). The Ambiguity of Play. Cambridge and London: Harvard University Press.

Tioli, E. (2006). Dallo spazio aptico alla rappresentazione immaginativo-motoria [From the haptic space to the imaginative-motor representation]. Tiflologia per l'integrazione, 6, 4-16. 
Troster, H., \& Brambring, M. (1994). The play-behavior and play materials of blind and sighted infants and preschoolers. Journal of Visual Impairment and Blindness, 88(5), 421-432.

Tzvetkova, М. (1994). Играта при зрително затруднените деца. [Play in Visually Impaired Children]. Preschool Education, 7(8), 48-50.

Vygotskij, L.S. (1983). Собрание сочинений, том пятый: Основы Дефектологии. [Collected Works, Volume Five: Fundamentals of Defectology]. Moscow, RUS: Education.

Wills, D. M. (1968). Problems of play and mastery in the blind child. British Journal of Medical Psychology, 41, 213-222.

Zanandrea, M. (1998). Play, social interaction and motor development: practical activities for preschoolers with visual impairments. Journal of Visual Impairments and Blindness, 92(3), 176-188. 